\title{
LA PROPIETAT HORITZONTAL
}

Llei 49/1960, de 21 juliol, sobre propietat horitzontal (LPH) 


\section{CONCEPTE}

- De l'art. $396 \mathrm{CC}$ es desprèn que és un règim especial de propietat que s'estableix sobre un edifici quan els seus diferents pisos i locals són susceptibles d'aprofitament independent, perquè tenen eixida pròpia a un element comú de l'edifici o a la via pública.

- Segons l'art. 3 LPH, en aquest règim correspon a cada pis o local:

- a) El dret singular i exclusiu de propietat sobre un espai prou delimitat i susceptible d'aprofitament independent, amb els elements arquitectònics i instal-lacions de totes classes que estiguen compreses dins dels seus límits i servisquen exclusivament al propietari, així com el dels annexos que expressament hagen estat assenyalats en el títol, encara que estiguen situats fora de l'espai delimitat.

- b) La copropietat, amb la resta d'amos de pisos o locals, de la resta d'elements, pertinences i serveis comuns.

- Cada propietari pot lliurement disposar del seu dret, sense poder separar els elements que l'integren i sense que la transmissió del gaudi afecte les obligacions derivades d'aquest règim de propietat. 


\section{ÀMBIT D’APLICACIÓ (art. 2 LPH)}

- La LPH serà d'aplicació a:

- a) Les comunitats de propietaris constituïdes d'acord amb l'article 5 .

- b) Les comunitats que reunisquen els requisits establits en l'art. $396 \mathrm{CC}$ i que no hagen atorgat el títol constitutiu de la propietat horitzontal.

- c) Els complexos immobiliaris privats.

- d) Les subcomunitats, entenent com a tals les que resulten quan, d'acord amb el que es disposa en el títol constitutiu, diversos propietaris disposen, en règim de comunitat, per al seu ús i gaudi exclusiu, de determinats elements o serveis comuns dotats d'unitat $\mathrm{i}$ independència funcional o econòmica.

- e) Les entitats urbanístiques de conservació, en els casos en què així ho disposen els seus estatuts. 


\section{ENTITATS URBANÍSTIQUES DE CONSERVACIÓ}

- Tenen personalitat jurídica pròpia, i es regeixen pels seus propis estatuts aprovats per l'ajuntament o òrgan administratiu competent, i tenen per finalitat fer els treballs de conservació i manteniment de les obres de la urbanització, dotacions i instal-lacions dels serveis públics, quan no estiguen a càrrec de l'administració actuant.

- Regulades en el Reglament de Gestió Urbanística de 25 agost 1978 (art. 24 a 30)

- La seua naturalesa administrativa els atorga el privilegi d'anar a la via de constrenyiment per a reclamar les quotes impagades dels propietaris. A més, no els resulta d'aplicació el règim de majories establit a la LPH, raó per la qual els acords s'adopten per majoria simple dels propietaris assistents a la junta general. 


\section{LA QUOTA, ELEMENT CENTRAL}

- A cada pis o local s'atribuirà una quota de participació en relació amb el total del valor de l'immoble i referida a centèsimes d'aquest.

- La quota serveix de mòdul per a determinar la participació en les càrregues i beneficis per raó de la comunitat. Les millores o menyscaptes de cada pis o local no alteraran la quota atribuïda, que sols pot variar-se d'acord amb el que s'estableix en els art. 10 i 17 LPH.

- L'acció de divisió no és procedent per a fer cessar la situació regulada per la LPH (art. 4). 


\section{EL TÍTOL CONSTITUTIU DE LA P.H.}

- Art. $5 \mathrm{LPH}$

- Descriu, a més de l'immoble en el seu conjunt, cada un dels pisos i locals, així com els serveis i instal-lacions de què dispose.

- En el mateix títol es fixa la quota de participació que correspon a cada pis o local. Per a la seua fixació es pren com a base la superfície útil de cada pis o local en relació amb el total de l'immoble, el seu emplaçament interior o exterior, la seua situació i l'ús que es presumisca racionalment que s'efectuarà dels serveis o elements comuns. 


\section{NORMES DE RĖGIM INTERIOR}

- Per a regular els detalls de la convivència i la utilització adequada dels serveis i coses comunes, i dins dels límits establits per la Llei i els estatuts, el conjunt de propietaris pot fixar normes de règim interior que obligaran també a tot titular mentre no siguen modificades en la forma prevista per a prendre acords sobre l'administració. 


\section{FACULTATS I PROHIBICIONS (art. 7)}

- 1. El propietari de cada pis o local podrà modificar els seus elements arquitectònics, instal·lacions o serveis quan no menystinga o altere la seguretat de l'edifici, la seua estructura general, la seua configuració o estat exteriors, o perjudique els drets d'altre propietari.

- 2. Al propietari i a l'ocupant del pis o local no els és permès fer activitats prohibides en els estatuts, que resulten damnoses per a la finca o que contravinguen les disposicions generals sobre activitats molestes, insalubres, nocives, perilloses o il·lícites.

- El president de la comunitat, a iniciativa pròpia o de qualsevol dels propietaris o ocupants, requerirà a qui faça les activitats prohibides la seua immediata cessació, i advertirà d'emprendre les accions judicials escaients.

- Si l'infractor persisteix en la conducta, el president, prèvia autorització de la junta de propietaris, pot exercir contra ell acció de cessació que, en el que no és previst expressament per aquest article, se substanciarà mitjançant el judici ordinari. 


\section{OBLIGACIONS DE CADA PROPIETARI}

\section{(art. 9)}

- a) Respectar les instal·lacions generals de la comunitat i resta d'elements comuns, fent-ne un ús correcte.

- b) Mantenir en bon estat de conservació el seu propi pis o local i instal-lacions privatives, i rescabalar els danys que ocasione per la seua manca d'atenció o de les persones per les quals haja de respondre.

- c) Consentir en el seu habitatge o local les reparacions exigides pel servei de l'immoble i permetre-hi les servituds imprescindibles requerides per a la realització d'obres, actuacions o la creació de serveis comuns, tenint dret a ser rescabalat per la comunitat dels danys i perjudicis ocasionats.

- d) Permetre l'entrada al seu pis o local als efectes abans previnguts.

- e) Contribuir, segons la quota de participació fixada en el títol o al que s'hi establisca especialment, a les despeses generals per a sostenir l'immoble. 


\section{OBLIGACIONS DE CADA PROPIETARI (art. 9, segueix)}

- f) Contribuir, segons la seua respectiva quota de participació, a la dotació del fons de reserva que existirà en la comunitat de propietaris per a atendre obres de conservació, reparació i rehabilitació de la finca, així com la realització de les obres d'accessibilitat esmentades en l'article 10.1b.

- El fons de reserva i no pot ser inferior al $10 \%$ del darrer pressupost de la comunitat.

- Amb càrrec al fons de reserva la comunitat pot subscriure un contracte d'assegurança que cobrisca els danys causats en la finca o bé concloure un contracte de manteniment permanent de l'immoble i les seues instal-lacions generals.

- g) Observar la diligència deguda en l'ús de l'immoble i en les seues relacions amb la resta de titulars, i respondre davant d'ells de les infraccions comeses i dels danys causats.

- h) Comunicar al secretari de la comunitat el domicili a Espanya a efectes de citacions i notificacions de tota mena relacionades amb la comunitat. En defecte de comunicació, es tindrà com a domicili per a citacions i notificacions el pis o local pertanyent a la comunitat, i tindrà plens efectes jurídics les entregades a qui estiga ocupant-lo.

- i) Comunicar al secretari de la comunitat el canvi de titularitat de l'habitatge o local. 


\section{ACTUACIONS OBLIGATÒRIES PER A LA COMUNITAT (art. 10)}

- a) Treballs i obres que resulten necessàries per al manteniment i compliment del deure de conservació de l'immoble i dels seus serveis i instal·lacions comunes.

- b) Actuacions per a assegurar l'accessibilitat universal, i en tot cas, les requerides a instància dels propietaris en l'habitatge o local dels quals visquen, treballen o presten serveis voluntaris, persones amb discapacitat, o majors de 70 anys, sempre que l'import repercutit anualment, una volta descomptades les subvencions públiques, no excedisca de 12 mensualitats ordinàries de despeses comunes.

- c) L'ocupació d'elements comuns de l'edifici pel temps que duren les obres anteriors.

- d) La construcció de noves plantes i qualsevol altra alteració que resulten preceptives a conseqüència de la inclusió de l'immoble en un àmbit d'actuació de rehabilitació o de regeneració i renovació urbana.

- e) Els actes de divisió material de pisos o locals per a formar-ne altres de més reduïts i independents, l'augment de la seua superfície per agregació d'altres adjacents del mateix edifici, o la seua disminució per segregació d'alguna part, quan aquestes actuacions siguen possibles perquè l'immoble és inclòs en un àmbit d'actuació de rehabilitació o de regeneració i renovació urbanes. 


\section{ÒRGANS DE GOVERN DE LA COMUNITAT (art. 13)}

- a) La junta de propietaris.

- b) El president i, si és el cas, els vicepresidents.

- c) El secretari.

- d) L'administrador.

- En els estatuts, o per acord majoritari de la junta de propietaris, poden establir-se altres òrgans de govern, sense menyscapte de les seues funcions i responsabilitats.

- Llevat que els estatuts ho disposen en contra, el nomenament dels òrgans es fa pel termini d'un any. Els designats poden ser remoguts del seu càrrec abans de l'expiració del mandat per acord de la junta de propietaris, convocada en sessió extraordinària.

- Quan el nombre de propietaris d'habitatges o locals de l'edifici no excedisca de quatre, poden acollir-se al règim d'administració de l'art. $398 \mathrm{CC}$, si expressament ho estableixen els estatuts. 


\section{JUNTA DE PROPIETARIS}

- Correspon a la junta de propietaris:

- a) Nomenar i remoure les persones que exercisquen els càrrecs i resoldre les reclamacions que els titulars dels pisos o locals formulen contra la seua actuació.

- b) Aprovar el pla de despeses i ingressos previsibles i els comptes.

- c) Aprovar els pressuposts i l'execució de totes les obres de reparació de la finca, i ser informada de les mesures urgents adoptades per l'administrador.

- d) Aprovar o reformar els estatuts i determinar les normes de règim interior.

- e) Conèixer i decidir en la resta d'assumptes d'interès general per a la comunitat, acordant les mesures escaients. 


\section{PRESIDENT}

- Serà nomenat, entre els propietaris, per elecció o, subsidiàriament, mitjançant torn rotatori o sorteig.

- El nomenament serà obligatori, tot i que el propietari designat pot sol-licitar el seu relleu al jutge dins del mes següent al seu accés al càrrec, invocant-ne les raons que l'assistisquen.

- Igualment es pot acudir al jutge quan, per qualsevol causa, fos impossible per a la junta designar president.

- El president ostenta legalment la representació de la comunitat, en judici i fora d'aquest, en tots els assumptes que l'afecten. 


\section{VICEPRESIDENTS}

- L'existència de vicepresidents és facultativa. Llur nomenament es fa pel mateix procediment que el de la designació del president.

- Correspon al vicepresident, o als vicepresidents pel seu ordre, substituir el president en els casos d'absència, vacant o impossibilitat, així com assistir-lo en l'exercici de les seues funcions en els termes que establisca la junta de propietaris. 


\section{SECRETARI I ADMINISTRADOR}

- Aquestes funcions són exercides pel president, llevat que els estatuts o la junta per acord majoritari, disposen la provisió d'aquests càrrecs separadament de la presidència.

- Els càrrecs de secretari i administrador poden acumular-se en una mateixa persona o bé nomenar-se independentment.

- El càrrec d'administrador i, si és el cas, el de secretariadministrador pot ser exercit per qualsevol propietari, així com per persones físiques amb qualificació professional suficient i legalment reconeguda per a exercir aquestes funcions. També pot recaure en corporacions i altres persones jurídiques en els termes establits en l'ordenament jurídic. 


\section{RÈGIM D'ADOPCIÓ D'ACORDS}

(art. 17)

- 1. La instal·lació d'infraestructures comunes per a l'accés als serveis de telecomunicació regulat en el RDL 1/1998, de 27 de febrer, o l'adaptació dels existents, així com la instal·lació de sistemes d'aprofitament d'energies renovables, o bé de les infraestructures necessàries per a accedir a nous subministraments energètics col·lectius, pot ser acordada, a petició de qualsevol propietari, per UN TERÇ dels integrants de la comunitat que representen UNTERÇ de les quotes de participació. 


\section{RÈGIM D'ADOPCIÓ D'ACORDS}

(art. 17)

- 2. Sense perjudici del que s'estableix en l'art. 10.1b, la realització d'obres o l'establiment de nous serveis comuns per a suprimir barreres arquitectòniques que dificulten l'accés o mobilitat de persones discapacitades i l'establiment del servei d'ascensor, fins $\mathrm{i}$ tot quan impliquen la modificació del títol constitutiu o dels estatuts, requereix el vot favorable de la MAJORIA DELS PROPIETARIS, que, al mateix temps, representen la MAJORIA DE LES QUOTES de participació. 


\section{RÈGIM D'ADOPCIÓ D'ACORDS}

(art. 17)

-3. L'establiment o la supressió dels serveis de porteria, consergeria, vigilància o altres serveis comuns d'interès general, suposen $o$ no modificació del títol constitutiu o dels estatuts, requereixen el vot favorable de 3/5 PARTS DEL TOTAL DELS PROPIETARIS, que, a més, representen 3/5 PARTS DE LES QUOTES de participació. 


\section{RÈGIM D'ADOPCIÓ D'ACORDS}

(art. 17)

- 5. La instal-lació d'un punt de recàrrega de vehicles elèctrics per a ús privat en l'aparcament de l'edifici, sempre que aquest s'ubique en una plaça individual de garatge, sols requereix la COMUNICACIÓ PRÈVIA a la comunitat. El cost d'aquesta instal-lació i el consum d'electricitat corresponent seran assumits íntegrament per l'interessat directe. 


\section{RÈGIM D'ADOPCIÓ D'ACORDS}

\section{(art. 17)}

- 6. Els acords no regulats expressament en aquest article, que impliquen l'aprovació o modificació de les regles contingudes en el títol constitutiu de la propietat horitzontal o en els estatuts, requereixen per a la seua validesa la UNANIMITAT del total dels propietaris que, a més, representen el TOTAL DE LES QUOTES.

- 7. Per a la validesa de la resta d'acords n'hi ha prou amb el vot de la MAJORIA DEL TOTAL DELS PROPIETARIS que, al mateix temps, representen la MAJORIA DE LES QUOTES de participació. En segona convocatòria, són vàlids els acords adoptats per la MAJORIA DELS ASSISTENTS, sempre que aquesta represente més de la meitat del valor de les quotes dels presents. 


\section{RÈGIM D'ADOPCIÓ D'ACORDS}

(art. 17)

- 12. L'acord pel qual es limita o condiciona l'exercici de l'activitat a què es refereix l'art. 5 e de la Llei 29/1994, de 24 de novembre, d'arrendaments urbans, en els termes establits en la normativa sectorial turística, requereix el vot favorable de 3/5 PARTS del total dels propietaris que, al mateix temps, representen 3/5 PARTS DE LES QUOTES de participació.

- Aquesta mateixa majoria es demana per a l'acord pel qual s'establisquen quotes especials de despeses o un increment en la participació de les despeses comunes de l'habitatge on es duga a terme aquesta activitat, sempre que aquestes modificacions no suposen un increment superior al 20\%. 


\section{IMPUGNACIÓ D’ACORDS (art. 18)}

- La impugnació dels acords és procedent quan:

- a) Siguen contraris a la llei o als estatuts.

- b) Resulten greument lesius per als interessos de la mateixa comunitat en benefici d'un o alguns propietaris.

- c) Suposen un greu perjudici per algun propietari o hi haja abús de dret.

- Estaran legitimats els propietaris que hagen salvat el seu vot en la junta, els absents per qualsevol causa i els qui indegudament hagen estat privats del seu dret de vot. Cal que estiga al corrent del pagament dels deutes vençuts o consignar judicialment el seu import.

- L'acció caducarà al cap de tres mesos de ser adoptat l'acord per la junta. Si són actes contraris a la llei o als estatuts, l'acció caducarà al cap d'un any.

- La impugnació dels acords de la junta no en suspèn l'execució, llevat que el jutge així ho dispose amb caràcter cautelar, a sol·licitud del demandant, oïda la comunitat de propietaris. 


\section{EXTINCIÓ DEL RĖGIM DE COMUNITAT (art. 23)}

- Per la destrucció de l'edifici, llevat de pacte en contra. S'entén produïda la destrucció quan el cost de la reconstrucció excedisca del 50\% del valor de la finca en el moment del sinistre, llevat que l'excés d'aquest cost estiga cobert per una assegurança.

- Per conversió en propietat o copropietat ordinàries. 